\title{
Hippocampal neuronal metal ion imbalance related oxidative stress in a rat model of chronic aluminum exposure and neuroprotection of meloxicam
}

\author{
Lijuan $Y u^{1}$, Rong Jiang ${ }^{2}$, Qiang Su${ }^{1}$, Huarong $Y u^{1 *}$ and Junqing Yang ${ }^{1 *}$
}

\begin{abstract}
Neurodegenerative diseases remain a significant unresolved societal burden afflicting millions of people worldwide. Neurons in the brain are highly sensitive to oxidative stress, which can be induced by metal toxicity. In this paper, a chronic aluminum overload-induced model of neurodegeneration was used to investigate whether metal ions ( $\mathrm{Al}, \mathrm{Fe}, \mathrm{Mn}, \mathrm{Cu}$ and $\mathrm{Zn}$ )-related oxidative stress was involved in neurodegenerative mechanism and to identify the protective action of meloxicam against rat hippocampal neuronal injury. The metal ion contents, activity of superoxide dismutase (SOD), and content of malondialdehyde (MDA) were detected. The results showed that the spatial learning and memory (SLM) function was significantly impaired in chronic aluminum overload rats. Considerable karyopycnosis was observed in hippocampal neurons. The SOD activity was weakened and the MDA content increased both significantly. In the hippocampus, Al, Fe, Mn, Cu, and Zn contents increased by $184.1 \%, 186.1 \%, 884.2 \%, 199.4 \%$ and $149.2 \%$, respectively. Meloxicam administration (without Al) had no effect compared with the control group, while meloxicam treatment with aluminum exposure significantly protected rats from SLM function impairment, neuron death, lower SOD activity, higher MDA content and brain metal ion imbalance. Our findings suggest that the cerebral metal ion imbalance-related oxidative stress is involved in mechanism of cerebral injury and neurodegeneration induced by chronic Al overload in rats, and that meloxicam protects neurons by reducing metal ion imbalance-related oxidative stress.
\end{abstract}

Keywords: Neurodegeneration, Metal ion, Meloxicam, Aluminum overload, Oxidative stress

\section{Introduction}

Neurodegenerative diseases (NDDs), including Alzheimer's disease (AD), Parkinson's disease (PD), Huntington's disease (HD), Amyotrophic lateral sclerosis (ALS), Spinal muscular atrophy (SMA) and related neurological and psychiatric disorders, encompass a group of neurological disorders. Neurodegeneration can be described as loss of neuronal structure and function, and is manifested as loss of memory, cognition, movement or its control, and sensation [1]. For example, $\mathrm{AD}$ is characterized by memory loss and cognitive impairment [2], PD can cause cognitive impairment, including dementia and behavioral changes [3], and HD is manifested with dementia, involuntary motor activity,

\footnotetext{
* Correspondence: 1370748729@qq.com; cqjqyang2004@aliyun.com 'Department of Pharmacology, Chongqing Key Laboratory of Biochemistry and Molecular Pharmacology, Medical College Rd. No 1, Chongqing Medical University, Chongqing 400016, P. R. China

Full list of author information is available at the end of the article
}

personality changes and cognitive impairment [4]. Though the current medical treatments have significantly improved the quality and length of life for NDD patients, NDDs remain a significant unresolved societal burden that afflicts millions of people worldwide.

NDDs are progressive, with reflective of increased neuron death. To date, the major mechanisms in pathogenic processes of NDDs include oxidative stress, protein aggregation, inflammation, blood brain barrier (BBB) disruption, and mitochondrial dysfunction. Oxidative stress is one major molecular mechanism responsible for the pathogenesis and progression of several NDDs [5]. Oxidative damage and mitochondrial dysfunction have been described in patients with $\mathrm{AD}, \mathrm{PD}, \mathrm{HD}$, and ALS [6,7]. The misfolding and aggregation of specific proteins underlie many NDDs [8], and otherwise, neurotoxicant exposure may play a role in neurodegeneration [9]. Nevertheless, much research on 
neurodegeneration is fragmentary, leaving the mechanisms of NDDs unresolved.

The available treatments for NDDs are inadequate. The mainstay of treatment for $\mathrm{AD}$ is agents that inhibit the degradation of acetyl-choline in the synapse [10]. Current treatment options for PD include deep brain stimulation or increasing dopamine levels by providing a dopamine precursor, L-dopa, or dopamine agonists [11-13]. However, these treatments are effective at early stage in relieving symptoms, but ineffectiveness and long-term side-effects will gradually occur along with PD progression. Moreover, boosting autophagy can reduce protein accumulation and avoid toxicity due to protein aggregation in NDDs [14], and the utilization of stem cells may attenuate neurodegeneration [15]. However, the treatments are generally designed to alleviate symptoms, rather than reversing the progression of neurodegeneration. Thereby, a concerted inquiry is needed to decipher the mechanisms of NDDs, and accelerate the discovery of efficacious therapies.

Neurons in the brain are highly sensitive to oxidative stress, which can be induced by metal toxicity [16]. Previous experiments show that $\mathrm{Al}$ overload caused mouse brain damage and an increased expression of cyclooxygenase2 (COX2) [17]. Meloxicam as a selective COX2 inhibitor significantly protected mice from the Aloverload-caused brain damage [17]. In the present study, we established the neurodegeneration models of Wistar rats by long-term intragastric administration of aluminum gluconate $[18,19]$, and investigated the changes of metal ion contents ( $\mathrm{Al}, \mathrm{Fe}, \mathrm{Mn}, \mathrm{Cu}, \mathrm{Zn}$ ), superoxide dismutase (SOD, an antioxidant enzyme) activity, and malondialdehyde (MDA, an oxidative stress biomarker) content. The aim of this study is to reveal whether the protective mechanism of meloxicam against rat hippocampal neuronal injury involves the reduction of the metal ion imbalance and oxidative stress.

\section{Materials and methods}

\section{Animals}

Experiments were approved by the Animal Laboratory Administrative Center and the Institutional Ethics Committee at Chongqing Medical University. Sixty male adult Wistar rats (obtained from Animal Laboratory Center of the University), weighing 200-250 g, were randomly and equally divided into 6 groups $(n=10)$ : a control group, a model group, $\mathrm{M}-1$ group, $\mathrm{M}-3$ group, $\mathrm{Al}+\mathrm{M}-1$ group, and $\mathrm{Al}+\mathrm{M}-3$ group $\left(\mathrm{M}-1\right.$ and $\mathrm{M}-3$ mean 1 and $3 \mathrm{mg} \cdot \mathrm{kg}^{-1}$ meloxicam respectively).

\section{Chemicals}

$\mathrm{AlCl}_{3} \cdot 6 \mathrm{H}_{2} \mathrm{O}$ (Sinopharm Chemical Reagent Co., Ltd., China) and sodium gluconate (Beijing Qing Sheng Da Chemical Technology Co., Ltd., China) were of analytical grade. Meloxicam was purchased from Kunshan Rotam Reddy Pharmaceutical Co., Ltd (China). Aluminum gluconate solution $\left(20 \mathrm{mg} \mathrm{Al} l^{3+} \cdot \mathrm{ml}^{-1}\right.$ ) was prepared on the day of experiments by adding $17.9 \mathrm{~g}$ of $\mathrm{AlCl}_{3} \cdot 6 \mathrm{H}_{2} \mathrm{O}$ and $9.9 \mathrm{~g}$ of sodium gluconate into $100 \mathrm{ml}$ of double distilled water $\left(\mathrm{ddH}_{2} \mathrm{O}\right)$ and then adjusted to about $\mathrm{pH} 6.0[18,19]$.

\section{Establishment of animal models}

The experiments were initiated after 3 days of acclimatization. The rats were treated by intragastric administration once a day, $5 \mathrm{~d}$ a week for 20 weeks as follows: the model group with $1 \mathrm{ml} / 100 \mathrm{~g}$ aluminum gluconate solution; the control group with the same volume of sodium gluconate solution; $\mathrm{M}-1$ group and $\mathrm{M}-3$ group with 1 and $3 \mathrm{mg} \cdot \mathrm{kg}^{-1}$ meloxicam, respectively; $\mathrm{Al}+\mathrm{M}-1$ group and $\mathrm{Al}+\mathrm{M}-3$ group with 1 and $3 \mathrm{mg} \cdot \mathrm{kg}^{-1}$ meloxicam respectively $30 \mathrm{~min}$ after administration of aluminum gluconate.

\section{Morris water maze test}

At the second day after stopping aluminum gluconate administration, the spatial learning and memory (SLM) function was evaluated in a Morris water maze, following a reported method [20]. The water maintained at $24-25^{\circ} \mathrm{C}$. In the learning stages, rats received 4 trials on each of 4 days. In each trial, a rat was placed into the water facing the pool wall, randomly from each of four starting positions. The trial was terminated and the latency was recorded when the rat found the platform

Table 1 Changes of spatial learning and memory function of chronic aluminum overload rats $(\operatorname{mean} \pm S D, n=10)$

\begin{tabular}{|c|c|c|c|c|c|}
\hline \multirow[t]{2}{*}{ Group } & \multicolumn{5}{|c|}{ Latency (s) } \\
\hline & Day 1 & Day 2 & Day 3 & Day 4 & Day 5 \\
\hline Control group & $100.21 \pm 9.38$ & $75.32 \pm 9.51$ & $42.16 \pm 7.24$ & $20.31 \pm 4.88$ & $14.24 \pm 3.38$ \\
\hline M-3 group & $96.28 \pm 8.51$ & $65.37 \pm 7.32$ & $33.46 \pm 6.27$ & $19.34 \pm 4.08$ & $12.04 \pm 3.22$ \\
\hline M-1 group & $104.36 \pm 12.14$ & $72.52 \pm 9.11$ & $40.66 \pm 7.16$ & $23.11 \pm 4.25$ & $15.43 \pm 4.39$ \\
\hline Model group & $158.42 \pm 24.03^{* *}$ & $102.56 \pm 11.36^{* *}$ & $70.53 \pm 7.58^{* *}$ & $53.16 \pm 6.24^{* *}$ & $45.14 \pm 6.13^{* *}$ \\
\hline $\mathrm{Al}+\mathrm{M}-3$ group & $99.33 \pm 9.18^{\# \#}$ & $69.51 \pm 8.17^{\# \#}$ & $38.69 \pm 5.11^{\# \# a}$ & $20.14 \pm 4.22^{\# \# a}$ & $16.14 \pm 4.10^{\# \# a}$ \\
\hline$A I+M-1$ group & $114.18 \pm 8.68^{\# \#}$ & $79.33 \pm 9.41^{\# \#}$ & $53.18 \pm 7.59^{\# \#}$ & $36.17 \pm 4.56^{\#}$ & $24.23 \pm 3.62^{\#}$ \\
\hline
\end{tabular}

${ }^{* *} \mathrm{P}<0.01$, vs. control group; ${ }^{\#} \mathrm{P}<0.05,{ }^{\# \#} \mathrm{P}<0.01$, vs. model group; ${ }^{\text {a }}<0.05$, vs. Al $+\mathrm{M}-1$ group; $\mathrm{M}-3$ group: meloxicam $3 \mathrm{mg} \cdot \mathrm{kg}{ }^{-1}$ group; $\mathrm{M}-1$ group: meloxicam $1 \mathrm{mg} \cdot \mathrm{kg}^{-1}$ group; $\mathrm{Al}+\mathrm{M}-3$ group: $\mathrm{Al}+$ meloxicam $3 \mathrm{mg} \cdot \mathrm{kg}^{-1}$ group; $\mathrm{Al}+\mathrm{M}-1$ group: $\mathrm{Al}+$ meloxicam $1 \mathrm{mg} \cdot \mathrm{kg}^{-1} \mathrm{group}$. 
within $180 \mathrm{~s}$. Otherwise, the trial was terminated and the rat was led to the platform. On the fifth day, the rats received a probe trial in which the platform was removed. The rat was placed into the water as before to test its memory about the previous position of the platform.

\section{Histology}

After the Morris water maze test, 3 rats from each group were perfused with heparinized saline $(100 \mathrm{ml})$ to remove blood from the vasculature, and then with $4 \%$ paraformaldehyde in phosphate buffered saline $(200 \mathrm{ml})$. The whole brain was then removed and stored in the same fixative.

\section{(a)}
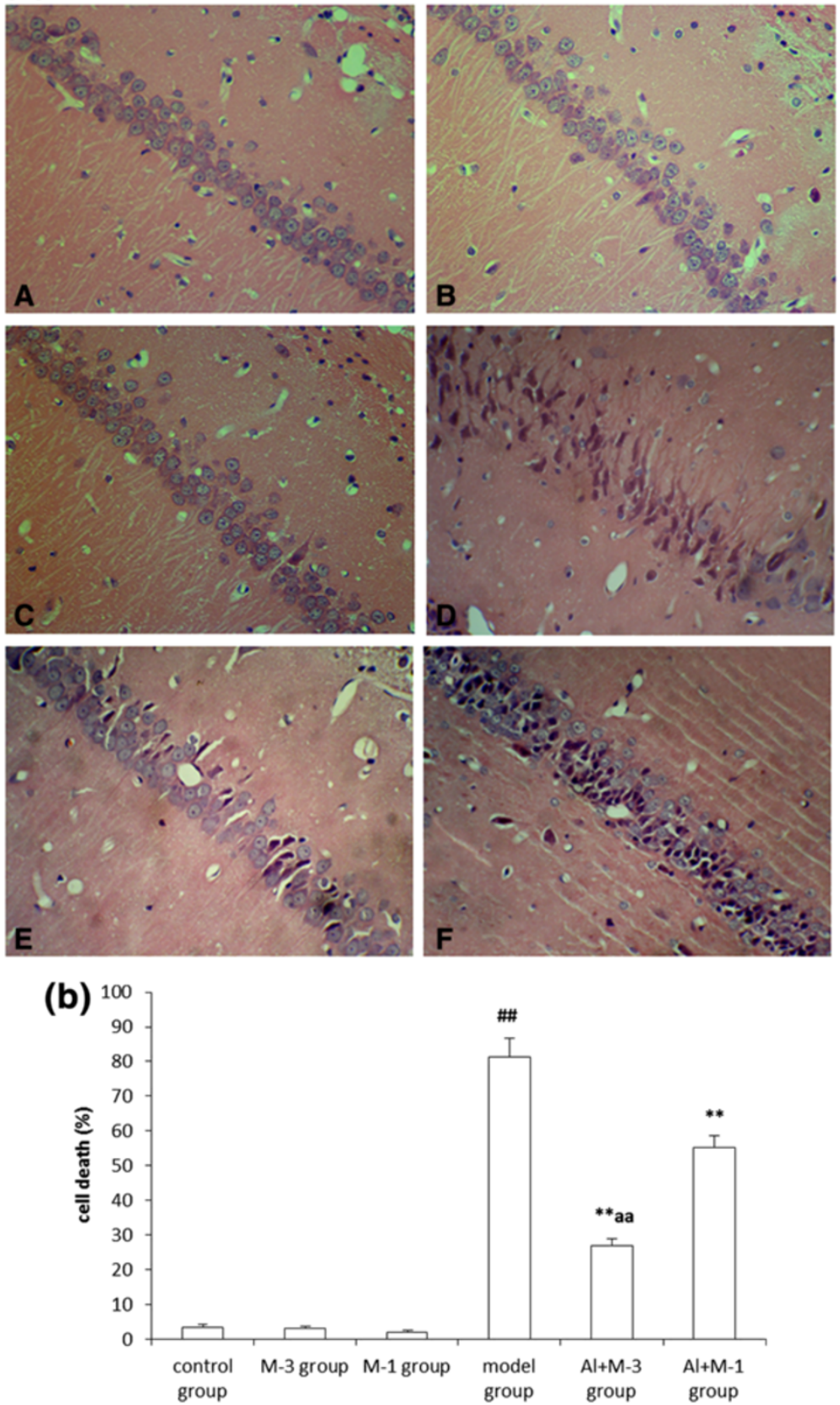

Figure 1 Changes of neuronal pathomorphology in chronic aluminum overload rat hippocampus. a. Neuronal pathomorphology in chronic aluminum overload rat hippocampus (HE $\times$ 400). A: Control group; B: Meloxicam $3 \mathrm{mg} \mathrm{kg}^{-1}$ group; C: Meloxicam $1 \mathrm{mg} \mathrm{kg} \mathrm{group}^{-1} \mathrm{D}$ : Model group; E: Al + Meloxicam 3 mg kg ${ }^{-1}$ group; F: Al + Meloxicam $1 \mathrm{mg} \mathrm{kg}^{-1}$ group. b. Group data showing the effect of meloxicam on the cell death rate. ${ }^{\# \#} \mathrm{P}<0.01$, vs. control group; ${ }^{* *} \mathrm{P}<0.01$, vs. model group; ${ }^{\text {aa }} \mathrm{P}<0.01$, vs. $\mathrm{Al}+\mathrm{M}-1$ group; $\mathrm{Al}+\mathrm{M}-3$ group: $\mathrm{Al}+\mathrm{meloxicam} 3 \mathrm{mg} \mathrm{kg}^{-1}$ group; $\mathrm{Al}+\mathrm{M}-1$ group: $\mathrm{Al}+$ meloxicam $1 \mathrm{mg} \mathrm{kg}^{-1}$ group (mean $\pm \mathrm{SD}, \mathrm{n}=3$ ). 
After paraffin embedding, 5- $\mu \mathrm{m}$ sections were obtained and stained with hematoxylin-eosin (H\&E). Morphologic changes of hippocampal neurons were examined using light microscopy. For cell counting from $H \& E$ stained sections, 9 consecutive high power fields were sampled from the hippocampal CA1 subfield. Cells with a distinct nucleus and nucleolus were regarded as intact neurons. Neurons were counted using a microscope at $400 \times$ magnification. The extent of cell death was estimated by the count of intact cells divided by the total cell count [21].

\section{SOD activity assay}

After Morris water maze test, 4 rat brains from each group were harvested. The hippocampi were homogenized with normal saline. Then SOD activity was detected using $0.05 \mathrm{ml}$ of $1 \%$ homogenate $(\mathrm{w} / \mathrm{v})$ according to the manual of SOD assay kit (Jiancheng Bioengineering Ltd, Nanjing, China). The absorbance of samples at $550 \mathrm{~nm}$ was detected with a spectrophotometer (722, Shanghai Jinghua Technology Instrument Co., Ltd). The protein content was measured by the method of coomassie brilliant blue.

\section{MDA content assay}

Hippocampal MDA content was detected according to the manual of the maleic dialdehyde assay kit (Jiancheng Bioengineering Ltd.). After Morris water maze test, brains were removed $(n=4)$. The hippocampi were homogenized with normal saline. MDA content was detected using $0.2 \mathrm{ml}$ of $10 \%$ homogenate $(\mathrm{w} / \mathrm{v})$. The absorbance at $532 \mathrm{~nm}$ was detected with the spectrophotometer. The protein content was measured by the method of coomassie brilliant blue.

\section{Metal content detection}

After Morris water maze test, 3 rat brains from each group were harvested. Each hippocampus was dissected and stored at $-80^{\circ} \mathrm{C}$ until metal analysis. To detect metal contents in the brain, the hippocampus was weighed and homogenized in $2 \mathrm{ml}$ of $\mathrm{ddH}_{2} \mathrm{O}$. All homogenates were digested in $8 \mathrm{ml} \cdot \mathrm{g}^{-1}$ wet brain of $25 \%$ tetraethyl ammonium hydroxide solution at $80^{\circ} \mathrm{C}$ for $24 \mathrm{~h}$, and the mixture was then adjusted to a final volume of $10 \mathrm{ml}$ with $\mathrm{ddH}_{2} \mathrm{O}$ and diluted 5 times before analysis. The tested metals were $\mathrm{Al}, \mathrm{Fe}, \mathrm{Mn}, \mathrm{Cu}$, and $\mathrm{Zn}$ and were analyzed by inductively coupled plasma-atomic emission spectrometry (ICP-AES). To avoid interference of metal ions, one-off plastic test tubes were used during procedures.

\section{Statistical analysis}

The results were expressed as mean \pm standard deviation (SD) and processed on SPSS 12.0 (SPSS Inc. Chicago, US). Within-group variances were compared by Dunnett's t-test.

\section{Results}

\section{Changes of SLM function}

The time taken to find the platform (latency) in the model group was significantly longer compared with the control group. The latency in both $\mathrm{Al}+\mathrm{M}-1$ and $\mathrm{Al}+\mathrm{M}-3$ groups was significantly shortened in a dose-dependent manner compared with the model group. There was no significant difference among the control, M-1 and M-3 groups (Table 1).

\section{Changes of neuronal pathomorphology}

The hippocampal neurons were in distinct and regular structure, and arranged densely and clearly in the control, M-1 and M-3 groups. In contrast, the model group revealed significant injuries including remarkable cell loss and karyopycnosis in hippocampal neurons. Dead and dying cells in the injured hippocampi displayed necrosis, karyopycnosis and irregular contours. The cell loss and karyopycnosis were significantly diminished in the $\mathrm{Al}+\mathrm{M}-3$ group in particular and the $\mathrm{Al}+\mathrm{M}-1$ group (Figure 1a). Quantification of remaining, the $\mathrm{Al}+\mathrm{M}-3$ group $(\mathrm{P}<0.01)$ and the $\mathrm{Al}+\mathrm{M}-1$ group $(\mathrm{P}<0.01)$ exhibited $27.96 \%$ and $54.05 \%$ reduction in cell death, respectively compared with the model group. There was significant difference between the $\mathrm{Al}+\mathrm{M}-3$ group and the $\mathrm{Al}+\mathrm{M}-1$ group $(\mathrm{P}<0.01)$, but no significant difference among the control, $M-1$ and $M-3$ groups (Figure 1b).

\section{Changes of SOD activity}

SOD activity in chronic aluminum overload rats distinctly decreased compared with the control group. Meloxicam administration significantly reversed the decrease of SOD activity caused by aluminum overload, especially in the $\mathrm{Al}$ + M-3 group. And there was no significant difference among the control, M-1 and M-3 groups (Table 2).

\section{Changes of MDA content}

MDA content in the model group significantly increased compared to the control group. Meloxicam administration significantly blunted the increase of MDA content

Table 2 Changes of SOD activity of chronic aluminum overload rat hippocampus (mean $\pm S D, n=4$ )

\begin{tabular}{ll}
\hline Group & SOD $\left(\mathbf{U} \cdot \mathbf{~ m g}^{-1}\right)$ \\
\hline Control group & $10.84 \pm 1.75$ \\
meloxicam $3 \mathrm{mg} \cdot \mathrm{kg}^{-1}$ group & $11.03 \pm 1.54$ \\
meloxicam $1 \mathrm{mg} \cdot \mathrm{kg}^{-1}$ group & $10.22 \pm 1.37$ \\
Model group & $8.09 \pm 0.72^{*}$ \\
$\mathrm{Al}+$ meloxicam $3 \mathrm{mg} \cdot \mathrm{kg}^{-1}$ group & $14.99 \pm 1.40^{\# \mathrm{~b}}$ \\
$\mathrm{Al}+$ meloxicam $1 \mathrm{mg} \cdot \mathrm{kg}^{-1}$ group & $9.81 \pm 0.97^{\#}$
\end{tabular}

${ }^{*} \mathrm{P}<0.05$, vs. control group; ${ }^{\#} \mathrm{P}<0.05$, vs. model group; ${ }^{\mathrm{b}} \mathrm{P}<0.01$, vs. $\mathrm{Al}+$ meloxicam $1 \mathrm{mg} \cdot \mathrm{kg}^{-1}$ group.

SOD: superoxide dismutase.

$\mathrm{U} \cdot \mathrm{mg}^{-1}$ : Unit per $\mathrm{mg}$ of protein. 
Table 3 Changes of MDA content of chronic aluminum overload rat hippocampus (mean $\pm S D, n=4$ )

\begin{tabular}{ll}
\hline Group & MDA $\left(\mathbf{n m o l} \cdot \mathbf{~ m g}^{-1}\right)$ \\
\hline Control group & $0.57 \pm 0.07$ \\
meloxicam $3 \mathrm{mg} \cdot \mathrm{kg}^{-1}$ group & $0.54 \pm 0.08$ \\
meloxicam $1 \mathrm{mg} \cdot \mathrm{kg}^{-1}$ group & $0.56 \pm 0.05$ \\
Model group & $1.32 \pm 0.22^{*}$ \\
$\mathrm{Al}+$ meloxicam $3 \mathrm{mg} \cdot \mathrm{kg}^{-1}$ group & $0.41 \pm 0.02^{\# \mathrm{~b}}$ \\
$\mathrm{Al}+$ meloxicam $1 \mathrm{mg} \cdot \mathrm{kg}^{-1}$ group & $0.60 \pm 0.06^{\#}$
\end{tabular}

${ }^{*} \mathrm{P}<0.05$, vs. control group; ${ }^{\#} \mathrm{P}<0.05$, vs. model group; ${ }^{\mathrm{b}} \mathrm{P}<0.01$, vs. $\mathrm{Al}+$ meloxicam $1 \mathrm{mg} \cdot \mathrm{kg}^{-1}$ group

MDA: malondialdehyde.

$\mathrm{nmol} \cdot \mathrm{mg}^{-1}$ : nmol per $\mathrm{mg}$ of protein.

in chronic aluminum overload rats. There was no significant difference among the control, M-1 and M-3 groups (Table 3).

\section{Changes of metal ion contents}

\section{Al}

$\mathrm{Al}$ content in the model group was significantly increased by $184.1 \%$ compared with the control group. There was no significant difference among the control, $\mathrm{M}-1$ and $\mathrm{M}-3$ groups. $\mathrm{Al}$ content significantly decreased in the $\mathrm{Al}+\mathrm{M}-3$ group in particular and the $\mathrm{Al}+\mathrm{M}-1$ group compared with the model group (Figure 2).

\section{$\mathrm{Fe}$}

Fe content in the rat hippocampus was the highest among the tested metals ( $\mathrm{Al}, \mathrm{Fe}, \mathrm{Mn}, \mathrm{Cu}$ and $\mathrm{Zn}$ ) in the control group. Fe contents of the M-1 and the M-3 groups were equal to that of the control group. Fe content in the model group was significantly increased by $186.1 \%$ compared with the control group. Meloxicam administration significantly decreased the $\mathrm{Fe}$ contents in the $\mathrm{Al}+\mathrm{M}-3$ and $\mathrm{Al}+\mathrm{M}-1$ groups, and there was significant difference between the two groups (Figure 3).
$\mathrm{Mn}$

Mn content in the rat hippocampus was the lowest among the tested metals. Mn content of the model group increased by $884.2 \%$ compared with control group. Considering the increasing ratio, Mn content increased the most severely. There was no significant difference among the control, M-1 and M-3 groups. Mn contents of the $\mathrm{Al}+\mathrm{M}-3$ group in particular and the $\mathrm{Al}+\mathrm{M}-1$ group significantly decreased compared with the model group (Figure 4).

\section{$\mathrm{Cu}$}

$\mathrm{Cu}$ content of the model group significantly increased by $199.4 \%$ compared with the control group. $\mathrm{Cu}$ contents of the $\mathrm{M}-1$ and $\mathrm{M}-3$ groups were equal to that of the control group. Meloxicam administration significantly decreased the $\mathrm{Cu}$ contents in the $\mathrm{Al}+\mathrm{M}-3$ and $\mathrm{Al}+\mathrm{M}-1$ groups, and there was significant difference between the two groups (Figure 5).

\section{$\mathrm{Zn}$}

$\mathrm{Zn}$ content of the model group significantly increased by $149.2 \%$ compared with the control group. There was no significant difference among the control, M-1 and $\mathrm{M}-3$ groups. $\mathrm{Zn}$ contents of the $\mathrm{Al}+\mathrm{M}-3$ group in particular and the $\mathrm{Al}+\mathrm{M}-1$ group significantly decreased (Figure 6).

\section{Discussion}

Metal ions are required for maintaining the functions of many proteins and proper metal ion balance in the brain is significant for normal cognitive function [22]. Thus, metal ions have received exponentially increasing interest. Growing evidence has been collected on the relationship between metal ions and the development of neurological disorders, such as metal-protein association inducing protein aggregation and metal-catalyzed protein oxidation inducing protein damage and/or generation of reactive

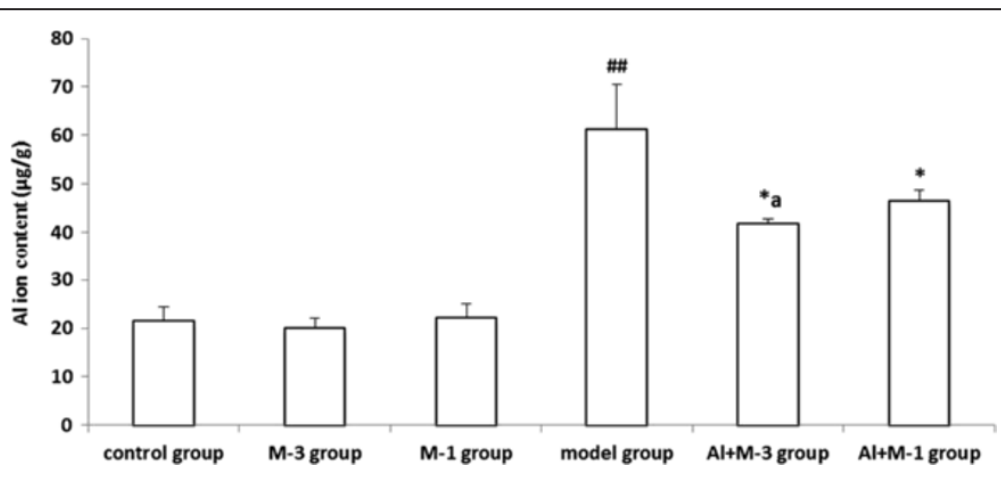

Figure 2 Changes of aluminum content of chronic aluminum overload rat hippocampus (mean $\pm S D, \mathbf{n}=3$ ). ${ }^{\# \#} P<0.01$, vS. control group; ${ }^{*} \mathrm{P}<0.05$, vs. model group; ${ }^{a} \mathrm{P}<0.05$, vs. Al $+\mathrm{M}-1$ group; $\mathrm{M}-3$ group: meloxicam $3 \mathrm{mg} \cdot \mathrm{kg}^{-1}$ group; $\mathrm{M}-1$ group: meloxicam $1 \mathrm{mg} \cdot \mathrm{kg}^{-1} \mathrm{group} ; \mathrm{Al}+\mathrm{M}-3$ group: $\mathrm{Al}+$ meloxicam $3 \mathrm{mg} \cdot \mathrm{kg}^{-1}$ group; $\mathrm{Al}+\mathrm{M}-1$ group: $\mathrm{Al}+$ meloxicam $1 \mathrm{mg} \cdot \mathrm{kg}^{-1} \mathrm{group} . \mu \mathrm{g} / \mathrm{g}: \mu \mathrm{gg}$ per $\mathrm{g}$ of wet weight tissue. 


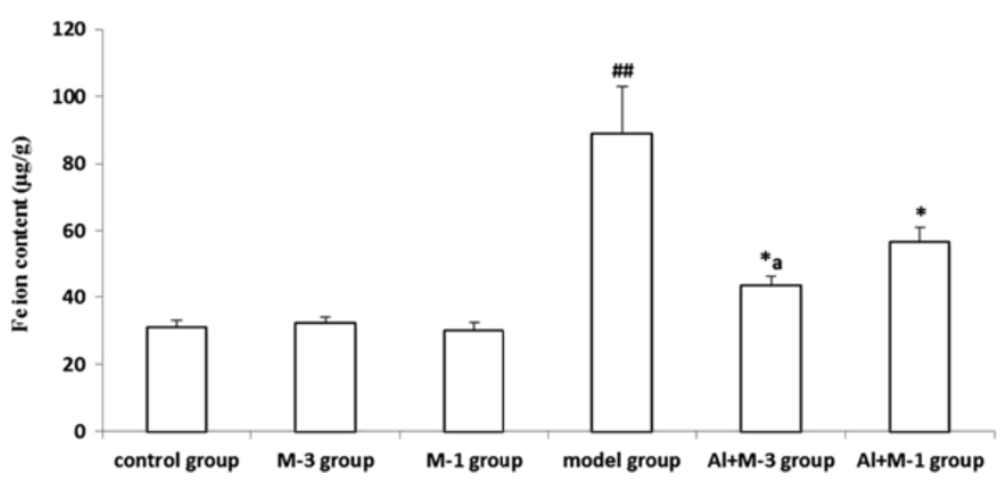

Figure 3 Changes of iron content of chronic aluminum overload rat hippocampus (mean $\pm S D, \mathbf{n}=3$ ). ${ }^{\# \#} P<0.01$, vs. control group; ${ }^{*} \mathrm{P}<0.05$, vs. model group; ${ }^{\mathrm{P}}<0.05$, vs. Al $+\mathrm{M}-1$ group; $\mathrm{M}-3$ group: meloxicam $3 \mathrm{mg} \cdot \mathrm{kg}^{-1}$ group; $\mathrm{M}-1$ group: meloxicam $1 \mathrm{mg} \cdot \mathrm{kg}^{-1} \mathrm{group} ; \mathrm{Al}+\mathrm{M}-3$ group: $\mathrm{Al}+$ meloxicam $3 \mathrm{mg} \cdot \mathrm{kg}^{-1}$ group; $\mathrm{Al}+\mathrm{M}-1$ group: $\mathrm{Al}+$ meloxicam $1 \mathrm{mg} \cdot \mathrm{kg}^{-1} \mathrm{group} . \mu \mathrm{g} / \mathrm{g}: \mu \mathrm{g}$ per $\mathrm{g}$ of wet weight tissue.

oxygen species (ROS) [23,24]. Metals such as $\mathrm{Al}, \mathrm{Fe}, \mathrm{Cu}$, and $\mathrm{Zn}$ were dysregulated in $\mathrm{AD}$ brain tissue to create a pro-oxidative environment [25-29]. In the frontal cortex of young and aged rats fed with $\mathrm{AlCl}_{3}$, the $\mathrm{Al}, \mathrm{Fe}$ and $\mathrm{Zn}$ contents significantly increased and $\mathrm{Al}$ may be linked with alteration in neurobehavioral activity [30]. The multifunctional metal-ion chelators as a potential treatment for metal-promoted neurodegenerative diseases (MpND) has attracted much attention and showed promise of diseasemodifying [31-34].

$\mathrm{Al}$ as an important neurotoxin has been investigated extensively both in vitro and in vivo, and is associated with cognitive dysfunction and various mental diseases. Recent neuropathological, biochemical, and epidemiological studies suggest that $\mathrm{Al}$ contributes to the progression of several NDDs, including $\mathrm{AD}$, and $\mathrm{PD}$, but the precise mechanism has not been clarified yet [30,35-37]. Intracerebroventricular (icv) injection of trace $\mathrm{AlCl}_{3}$ into mice will result in neurodegeneration and learning/memory disorders [38]. However, oral ingestion is the main form of $\mathrm{Al}$ exposure in clinic. Because the icv animal models do not much resemble that from oral ingestion of $\mathrm{Al}$, several scientists hold that the icv $\mathrm{AlCl}_{3}$ injection model does not strictly speak a neurodegeneration model. In the present study, we established neurodegenerative models by intragastric administration of aluminum gluconate $(200 \mathrm{mg}$ $\mathrm{Al}^{3+} \cdot \mathrm{Kg}^{-1}$, once a day, $5 \mathrm{~d}$ a week, for 20 weeks) $[18,19]$. The results showed that the SLM function was significantly impaired and significant karyopycnosis of hippocampal neurons was observed in the model group compared with the control group.

$\mathrm{Al}$ neurotoxicity may be related to the integrity and permeability of $\mathrm{BBB}$ [39]. Al can induce apoptosis in rat hippocampal cells through the down-regulation of bcl-2 mRNA expression and the up-regulation of bax mRNA expression [40]. Al may also be involved in the aggregation of $A \beta$ peptides, inducing $A \beta$ peptides into the $\beta$-sheet structure and facilitating iron-mediated oxidative reactions [41]. Neurodegeneration caused by aluminum overload was associated with an imbalance in metal ion levels in the brain. Metal dyshomeostasis is linked in protein misfolding and may contribute to oxidative stress and neuronal damage. The presence of $\mathrm{Al}$ might change the contents of endogenous trace metals [42].

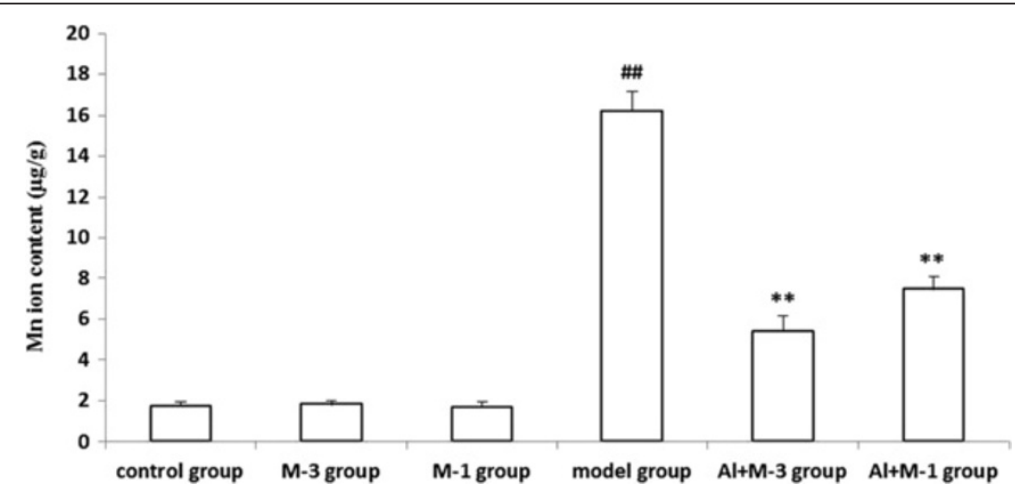

Figure $\mathbf{4}$ Changes of manganese content of chronic aluminum overload rat hippocampus (mean $\pm \mathrm{SD}, \mathbf{n}=3$ ). $\#$ P $<0.01$, vS. control group; ${ }^{*}$ P < 0.01, vs. model group; M-3 group: meloxicam $3 \mathrm{mg} \cdot \mathrm{kg}^{-1}$ group; $\mathrm{M}-1$ group: meloxicam $1 \mathrm{mg} \cdot \mathrm{kg}^{-1} \mathrm{group} ; \mathrm{Al}+\mathrm{M}-3 \mathrm{group}$ : Al + meloxicam $3 \mathrm{mg} \cdot \mathrm{kg}^{-1}$ group; $\mathrm{Al}+\mathrm{M}-1$ group: Al + meloxicam $1 \mathrm{mg} \cdot \mathrm{kg}^{-1}$ group. $\mu \mathrm{g} / \mathrm{g}: \mu \mathrm{g}$ per $\mathrm{g}$ of wet weight tissue. 


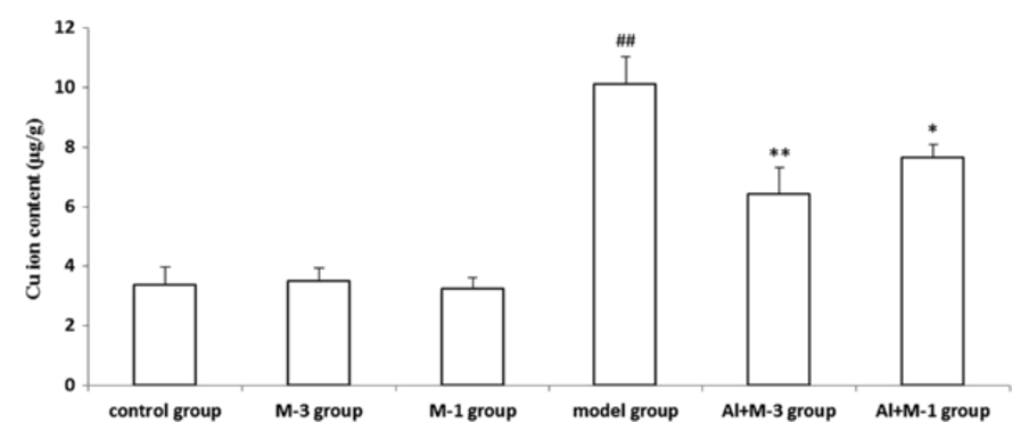

Figure 5 Changes of copper content of chronic aluminum overload rat hippocampus (mean $\pm S D, n=3$ ). ${ }^{\# \#} P<0.01$, vs. control group; ${ }^{*} \mathrm{P}<0.05$, ${ }^{*} \mathrm{P}<0.01$, vs. model group; $\mathrm{M}-3$ group: meloxicam $3 \mathrm{mg} \cdot \mathrm{kg}^{-1}$ group; $\mathrm{M}-1$ group: meloxicam $1 \mathrm{mg} \cdot \mathrm{kg}^{-1} \mathrm{group} ; \mathrm{Al}+\mathrm{M}-3 \mathrm{group}$ : $\mathrm{Al}+$ meloxicam $3 \mathrm{mg} \cdot \mathrm{kg}^{-1}$ group; $\mathrm{Al}+\mathrm{M}-1$ group: $\mathrm{Al}+$ meloxicam $1 \mathrm{mg} \cdot \mathrm{kg}^{-1}$ group. $\mu \mathrm{g} / \mathrm{g}: \mu \mathrm{g}$ per $\mathrm{g}$ of wet weight tissue.

Iron as an important trace element is essential for neuron development since it is required for various physiological events, including mitochondrial respiration, oxygen transport and DNA synthesis [43]. However, iron contributes to oxidative stress through Fenton reaction, leading to damages in DNA, proteins and membrane $[44,45]$. Iron imbalance is a precursor to the neurodegenerative processes leading to $\mathrm{AD}$ [46], and quantification of brain iron content can be an effective marker for early diagnosis of $\mathrm{AD}$ [47]. Iron accumulation may contribute to protein aggregation and neuronal death in PD patients [48]. Excessive iron would induce cell injury by reacting with $\mathrm{H}_{2} \mathrm{O}_{2}$ to produce hydroxyl radical $\left(\mathrm{OH}^{-}\right)$, superoxide anions $\left(\mathrm{O}_{2}{ }^{-}\right)$, and ROS [49]. Another hypothesis states that iron-mediated free radical production contributes to $\mathrm{BBB}$ opening to cause neuronal damage [50]. In our study, the iron content in the model group was significantly higher compared with the control group, and iron content was the highest among the tested metals, implying that iron overload in hippocampus may play an important role in the occurrence of neuron damage.

Other transitional metals such as $\mathrm{Mn}, \mathrm{Cu}$, and $\mathrm{Zn}$ are essential enzyme cofactors required for numerous cellular processes, but their abnormal accumulation in the brain will lead to neurotoxicity [22]. Mn has long been known to cause neurological disorders similar to PD. Mn might result in movement abnormalities in PD patients [51]. The present study revealed that $\mathrm{Mn}$ content in hippocampus of the model group was 8.8 times (the highest ratio) higher compared with the control group. The mechanism of $\mathrm{Mn}$-induced neurotoxicity has not been fully elucidated, but an established mechanism is correlated with attenuated uptake of glutamate (GSH) [52]. Mn can reduce brain glutathione level, likely reflecting oxidative stress [53], and might lead to mitochondrial dysfunction and trigger apoptotic-like neuronal death [54]. These studies indicate that the obvious increase of Mn content in hippocampus may play a key role in the mechanism of chronic Alinduced brain damage and neural degeneration.

$\mathrm{Cu}$ which is released at the synaptic cleft is an important structural cofactor in a series of biochemical processes with a narrow-range of optimal content [55]. The knowledge of $\mathrm{Cu}$ homeostasis has become increasingly important in clinical medicine, as it can be involved in the pathogenesis of NDDs such as AD [56-59]. The mechanism may be that $\mathrm{Cu}$ affects the degradation and aggregation

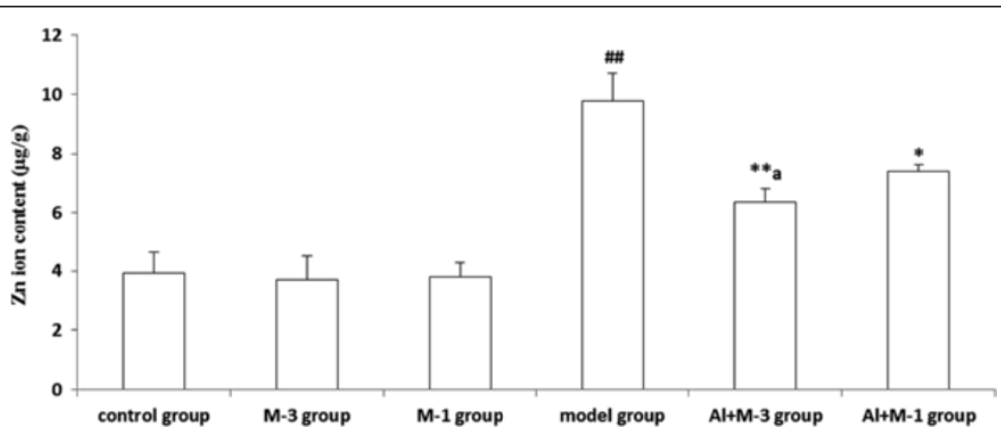

Figure 6 Changes of zinc content of chronic aluminum overload rat hippocampus (mean $\pm S D, n=3$ ). ${ }^{\# \#} P<0.01$, vs. control group; ${ }^{*} \mathrm{P}<0.05$, ${ }^{* *} \mathrm{P}<0.01$, vs. model group; ${ }^{\mathrm{P}} \mathrm{P}<0.05$, vs. Al $+\mathrm{M}-1$ group; $\mathrm{M}-3$ group: meloxicam $3 \mathrm{mg} \cdot \mathrm{kg}^{-1}$ group; M-1 group: meloxicam $1 \mathrm{mg} \cdot \mathrm{kg}^{-1}$ group; $\mathrm{Al}+\mathrm{M}-3$ group: $\mathrm{Al}+$ meloxicam $3 \mathrm{mg} \cdot \mathrm{kg}^{-1}$ group; $\mathrm{Al}+\mathrm{M}-1$ group: $\mathrm{Al}+$ meloxicam $1 \mathrm{mg} \cdot \mathrm{kg}^{-1}$ group. $\mu \mathrm{g} / \mathrm{g}$ : $\mu \mathrm{g}$ per $\mathrm{g}$ of wet weight tissue. 
of $\mathrm{A} \beta$ in $\mathrm{AD}[60,61]$. We found that $\mathrm{Cu}$ content significantly increased after 20-week administration of aluminum gluconate, and this may be a reason for the SLM function impairment and neuron death.

$\mathrm{Zn}$, essential for human health in trace amounts, is co-released with GSH and the significance of $\mathrm{Zn}$ signaling is gradually recognized [62]. Hippocampal pyramidal neurons are vulnerable to brain injury, while $\mathrm{Zn}$ entry may enhance this vulnerability [63]. Zn has been implicated in $\mathrm{AD}$ and PD. Excessive $\mathrm{Zn}$ translocation might be a molecular trigger of the cellular apoptosis $[64,65]$. In our experiments, the hippocampus of model rats showed $\mathrm{Zn}$ accumulation, and we thought that $\mathrm{Zn}$ is also involved in the occurrence of brain injury.

Neurons in brain are highly sensitive to oxidative stress. Metal toxicity is a problem leading to oxidative stress. Superoxide radicals can also create further oxidative stress by metal-catalyzed reactions [16]. SOD converts superoxide to $\mathrm{H}_{2} \mathrm{O}_{2}$ and oxygen. SODs are the most important antioxidant enzymes in the antioxidant defense system [66]. MDA is an end-product of lipid peroxidation and an excellent marker for degeneration of neurons [67]. Besides, metal ion contents in hippocampus of the model group significantly increased compared with the control group. The hippocampal SOD activity was weakened and MDA content increased both significantly in the model group. The results might further confirm the hypothesis that imbalance of cerebral metal ion is involved in occurrence of oxidative stress.

Moreover, meloxicam could significantly suppress metal ion elevation and prevent hippocampal neuron injury in aluminum overload rats. Reportedly, COX-2-induced synthesis of prostaglandins (PGs) was associated with chronic inflammation [68,69], causing oxidative stress. Our previous study showed that chronic aluminum overload significantly elevated COX2 mRNA and protein expressions [18]. These results suggest that as a selective COX2 inhibitor, meloxicam might alleviate oxidative stress damage to the brain by inhibiting COX2 activity, relieving inflammation and reducing metal ion imbalance. It may be involved in the neuroprotective mechanism of meloxicam against rat hippocampal neuronal injury following chronic aluminum overload.

In conclusion, we provide evidence that metal ion imbalance may contribute significantly to hippocampal injury caused by exposure to aluminum. Meloxicam was neuroprotective by decreasing COX2 expression and was associated with inhibition of oxidative stress. Clearly, further studies are necessary to clarify the neuroprotective mechanisms of meloxicam after exposure to aluminum.

\section{Competing interest}

The authors declare no conflicts of interest/disclosures.

\section{Authors' contributions}

LY contributed to the data collection, analyzed and interpreted the data, and wrote the manuscript. RJ and QS collected the data and conducted the experiments. HY and JY participated in the concept and design of the study and edited the manuscript. All authors read and approved the final manuscript.

\section{Acknowledgments}

This reported study was supported by research grants from the Natural Science Foundation of China (No. 81070972 and No.30672211).

\section{Author details}

${ }^{1}$ Department of Pharmacology, Chongqing Key Laboratory of Biochemistry and Molecular Pharmacology, Medical College Rd. No 1, Chongqing Medical University, Chongqing 400016, P. R. China. ${ }^{2}$ Department of Stem Cells and Tissue Engineering, Chongqing Medical University, Chongqing 400016, P. R. China.

Received: 2 September 2013 Accepted: 28 February 2014 Published: 11 March 2014

\section{References}

1. Ambegaokar SS, Roy B, Jackson GR: Neurodegenerative models in drosophila: polyglutamine disorders, Parkinson disease, and amyotrophic lateral sclerosis. Neurobiol Dis 2010, 40(1):29-39.

2. Reitz C, Brayne C, Mayeux R: Epidemiology of Alzheimer disease. Nat Rev Neurol 2011, 7(3):137-152.

3. Leverenz JB, Quinn JF, Zabetian C, Zhang J, Montine KS, Montine TJ: Cognitive impairment and dementia in patients with Parkinson disease. Curr Top Med Chem 2009, 9(10):903-912.

4. Vonsattel JP, DiFiglia M: Huntington disease. J Neuropath Exp Neur 1998 57:369-384.

5. Carletti B, Piemonte F, Rossi F: Neuroprotection: the emerging concept of restorative neural stem cell biology for the treatment of neurodegenerative diseases. Curr Neuropharmacol 2011, 9:313-317.

6. Albers DS, Beal MF: Mitochondrial dysfunction and oxidative stress in aging and neurodegenerative disease. J Neural Transm Supp/ 2000, 59:133-154.

7. Barnham KJ, Masters CL, Bush Al: Neurodegenerative diseases and oxidative stress. Nat Rev Drug Discov 2004, 3:205-214.

8. Jucker M, Walker LC: Pathogenic protein seeding in Alzheimer's disease and other neurodegenerative disorders. Ann Neurol 2011, 70(4):532-540.

9. Cannon JR, Greenamyre JT: The role of environmental exposures in neurodegeneration and neurodegenerative diseases. Toxicol Sci 2011, 4(2):225-250.

10. DeLaGarza WW: Pharmacologic treatment of Alzheimer's disease: an update. Am Fam Physician 2003, 68(7):1365-1372.

11. Krack P, Batir A, Van Blercom N, Chabardes S, Fraix V, Ardouin C, Koudsie A, Limousin PD, Benazzouz A, LeBas JF, Benabid AL, Pollak P: Five-year follow-up of bilateral stimulation of the subthalamic nucleus in advanced Parkinson's disease. N Engl J Med 2003, 349(20):1925-1934.

12. Benabid AL, Chabardes S, Mitrofanis J, Pollak P: Deep brain stimulation of the subthalamic nucleus for the treatment of Parkinson's disease. Lancet Neurol 2009, 8:67-81.

13. Poewe W: Treatments for Parkinson disease-past achievements and current clinical needs. Neurology 2009, 72:S65-S73.

14. Graziotto JJ, Cao K, Collins FS, Krainc D: Rapamycin activates autophagy in Hutchinson-Gilford progeria syndrome. Implications for normal aging and age-dependent neurodegenerative disorders. Autophagy 2012, 8(1):147-151.

15. Lunn JS, Sakowski SA, Hur J, Feldman EL: Stem cell technology for neurodegenerative diseases. Ann Neurol 2011, 70(3):353-361.

16. Jomova K, Vondrakova D, Lawson M, Valko M: Metals, oxidative stress and neurodegenerative disorders. Mol Cell Biochem 2010, 345:91-104.

17. Yang JQ, Liu BZ, He BC, Zhou QX: Protective effects of meloxicam on aluminum overload-induced cerebral damage in mice. Eur J Pharmacol 2006, 547(1-3):52-58.

18. Su Q, Yang JQ, Zhang P: Effect of meloxicam on cyclooxygenase 2 expression of chronic aluminum overload-induced nerve degeneration in rat hippocampus. Chin J Pharmacol Toxicol 2009, 23(1):6-10. 
19. Pan YQ, Zhang P, Yang JQ, Su Q: 5-lipoxygenase expression in a brain damage model induced by chronic oral administration of aluminum. Neural Regen Res 2010, 5(21):1634-1638.

20. Zhang J, Yang JQ, He BC, Zhou QX, Yu HR, Tang Y, Liu BZ: Berberine and total base from rhizoma coptis chinensis attenuate brain injury in an aluminum-induced rat model of neurodegenerative disease. Saudi Med J 2009, 30:760-766.

21. Kuang G, He Q, Zhang YM, Zhuang RC, Xiang AL, Jiang QS, Luo Y, Yang JQ Modulation of preactivation of PPAR- $\beta$ on memory and learning dysfunction and inflammatory response in the hippocampus in rats exposed to global cerebral ischemia/reperfusion. PPAR Res 2012:209794.

22. Nelson N: Metal ion transporters and homeostasis. EMBO J 1998 18(16):4361-4371.

23. Faller $P$, Hureau $C$ : Bioinorganic chemistry of copper and zinc ions coordinated to amyloid-beta peptide. Dalton Trans 2009, 7:1080-1094

24. Rauk A: The chemistry of Alzheimer's disease. Chem Soc Rev 2009, 38(9):2698-2715.

25. Lovell MA, Robertson JD, Teesdale WJ, Campbell JL, Markesbery WR: Copper, iron and zinc in Alzheimer's disease senile plaques. J Neuro/ Sci 1998, 158:47-52

26. Qian ZM, Wang Q: Expression of iron transport proteins and excessive iron accumulation in the brain in neurodegenerative disorders. Brain Res Rev 1998, 27:257-267.

27. Christen Y: Oxidative stress and Alzheimer disease. Am J Clin Nutr 2000, 71:621S-629S

28. Liu G, Garrett MR, Men P, Zhu XW, Perry G, Smith MA: Nanoparticle and other metal chelation therapeutics in Alzheimer disease. Biochim Biophys Acta 2005, 1741(3):246-252.

29. Miller LM, Wang Q, Telivala TP, Telivala TP, Smith RJ, Lanzirotti A, Miklossy J: Synchrotron-based infrared and $\mathrm{X}$-ray imaging shows focalized accumulation of $\mathrm{Cu}$ and $\mathrm{Zn}$ co-localized with beta-amyloid deposits in Alzheimer's disease. J Struct Biol 2006, 155(1):30-37.

30. Tripathi S, Mahdi AA, Nawab A, Chander R, Hasan M, Siddiqui MS, Mahdi F, Mitra K, Bajpai VK: Influence of age on aluminum induced lipid peroxidation and neurolipofuscin in frontal cortex of rat brain: a behavioral, biochemical and ultrastructural study. Brain Res 2009, 1253:107-116.

31. Barnham KJ, Bush Al: Metals in Alzheimer's and Parkinson's diseases. Curr Opin Chem Biol 2008, 12:222-228.

32. Jakob-Roetne $\mathrm{R}$, Jacobsen $\mathrm{H}$ : Alzheimer's disease: from pathology to therapeutic approaches. Angew Chem Int Ed 2009, 48:3030-3059.

33. Scott LE, Orvig C: Medicinal inorganic chemistry approaches to passivation and removal of aberrant metal ions in disease. Chem Rev 2009, 109:4885-4910.

34. Hureau C, Sasaki I, Gras E, Faller P: Two functions, one molecule: a metal-binding and a targeting moiety to combat Alzheimer's disease. Chem Bio Chem 2010, 11(7):950-953.

35. Méndez-Álvarez E, Soto-Otero R, Hermida-Ameijeiras A, López-Real M, Labandeira-García JL: Effects of aluminum and zinc on the oxidative stress caused by 6-hydroxydopamine autoxidation: relevance for the pathogenesis of Parkinson's disease. Biochim Biophys Acta 2002, 1586(2):155-168.

36. Ferreira PC, Piai KA, Takayanagui AMM, Segura-Muñoz SI: Aluminum as a risk factor for Alzheimer's disease. Rev Lat Am Enfermagem 2008, 16(1):151-157

37. Sánchez-Iglesias S, Méndez-Álvarez E, Iglesias-González J, Muñoz-Patiño A, Sánchez-Sellero I, Labandeira-García JL, Soto-Otero R: Brain oxidative stress and selective behaviour of aluminium in specific areas of rat brain: potential effects in a 6-OHDA-induced model of Parkinson's disease. J Neurochem 2009, 109(3):879-888.

38. He BC, Teng YZ, Yang JQ, Zhou QX: Experimental study on neurodegeneration induced by aluminum overload in mice. Ind Hith Occup Dis 2006, 32(3):153-157.

39. Song $Y$, Xue $Y X$, Liu X, Wang $P$, Liu L: Effects of acute exposure to aluminum on blood-brain barrier and the protection of zinc. Neurosci Lett 2008, 445:42-46.

40. Niu Q, Wang LP, Chen YL, Zhang HM: Relationship between apoptosis of rat hippocampus cells induced by aluminum and the copy of the bcl-2 as well as bax mRNA. J Hygiene Res 2005, 34(6):671-673.

41. Yumoto S, Kakimi S, Ohsaki A, Ishikawa A: Demonstration of aluminum in amyloid fibers in the cores of senile plaques in the brains of patients with Alzheimer's disease. J Inorg Biochem 2009, 103(11):1579-1584.
42. Yang MS, Wong $\mathrm{MH}$ : Changes in $\mathrm{Ca}, \mathrm{Cu}, \mathrm{Fe}, \mathrm{Mg}$, and $\mathrm{Zn}$ contents in mouse brain tissues after prolonged oral ingestion of brick tea liquor containing a high level of Al. Bio Trace Elem Res 2001, 80(1):67-76.

43. Hentze MW, Muchenthaler MU, Andrews NC: Balancing acts: molecular control of mammalian iron metabolism. Cell 2004, 117:285-297.

44. Ellen YY, Guo-Ross SS, Bondy SC: The stabilization of ferrous iron by a toxic $\beta$-amyloid fragment and by an aluminum salt. Brain Res 1999, 839:221-226.

45. Nappi AJ, Vass E: Iron metalloenzymes and cytotoxic reactions. Cell Mol Biol (Noisy-le-Grand) 2000, 46(3):637-647.

46. Smith MA, Zhu X, Tabaton M, Liu G Jr, McKeel DW, Cohen ML, Wang XL, Siedlak SL, Dwyer BE, Hayashi T, Nakamura M, Nunomura A, Perry G: Increased iron and free radical generation in preclinical Alzheimer disease and mild cognitive impairment. J Alzheimers Dis 2010, 19(1):363-372.

47. Leskovjan AC, Kretlow A, Lanzirotti A, Barrer R, Vogt S, Miller LM: Increased brain iron coincides with early plaque formation in a mouse model of Alzheimer's disease. Neuroimage 2011, 55(1):32-38.

48. Hirsch EC: Iron transport in Parkinson's disease. Parkinsonism Relat Disord 2009, 15(Suppl 3):S209-211.

49. Elseweidy MM, Abd El-Baky AE: Effect of dietary iron overload in rat brain: oxidative stress, neurotransmitter level and serum metal ion in relation to neurodegenerative disorders. Indian J Exp Biol 2008, 46(12):855-858.

50. Won SM, Lee JH, Park UJ, Gwag J, Gwag BJ, Lee YB: Iron mediates endothelial cell damage and blood-brain barrier opening in the hippocampus after transient forebrain ischemia in rats. Xp Mol Med 2011, 43(2):121-128.

51. Guilarte TR: Manganese and Parkinson's disease: a critical review and new findings. Environ Health Perspect 2010, 118(8):1071-1080

52. Aschner M, Guilarte TR, Schneider JS, Zheng W: Manganese: recent advances in understanding its transport and neurotoxicity. Toxicol Appl Pharmacol 2007, 221:131-147.

53. Santos AP, Santos ML, Batoréu MC, Aschner M: Prolactin is a peripheral marker of manganese neurotoxicity. Brain Res 2011, 1382:282-290.

54. Malecki EA: Manganese toxicity is associated with mitochondrial dysfunction and DNA fragmentation in rat primary striatal neurons. Brain Res Bull 2001, 55(2):225-228.

55. Kim BE, Nevitt T, Thiele DJ: Mechanisms for copper acquisition, distribution and regulation. Nat Chem Biol 2008, 4:176-185.

56. Rotilio G, Carri MT, Rossi L, Ciriolo MR: Copper-dependent oxidative stress and neurodegeneration. IUBMB Life 2000, 50:309-314.

57. Mercer JF: The molecular basis of copper-transport diseases. Trends Mol Med 2001, 7:64-69.

58. Strausak D, Mercer JF, Dieter HH, Stremmel W, Multhaup G: Copper in disorders with neurological symptoms: Alzheimer's, Menkes, and Wilson diseases. Brain Res Bull 2001, 55:175-185.

59. Squitti R, Pasqualetti P, Dal Forno G, Moffa F, Cassetta E, Lupoi D, Vernieri F, Rossi L, Baldassini M, Rossini PM: Excess of serum copper not related to ceruloplasmin in Alzheimer disease. Neurology 2005, 64:1040-1046.

60. Lin CJ, Huang HC, Jiang ZF: Cu(II) interaction with amyloid-beta peptide: a review of neuroactive mechanisms in AD brains. Brain Res Bull 2010, 82(5-6):235-242

61. Grasso G, Pietropaolo A, Spoto G, Spoto G, Pappalardo G, Tundo GR, Coletta M, Rizzarelli E: Copper(I) and copper(II) inhibit A $\beta$ peptides proteolysis by insulin-degrading enzyme differently: implications for metallostasis alteration in Alzheimer's disease. Chemistry 2011, 17(9):2752-2762.

62. Nuttall JR, Oteiza PI: Zinc and the aging brain. Genes Nutr 2014, 9(1):379.

63. Hellmich HL, Eidson KA, Capra BA, Garcia JM, Boone DR, Hawkins BE, Uchida T, Dewitt DS, Prough DS: Injured Fluoro-Jade-positive hippocampal neurons contain high levels of zinc after traumatic brain injury. Brain Res 2007, 1127(1):119-126

64. Frederickson CJ, Koh JY, Bush Al: The neurobiology of zinc in health and disease. Nat Rev Neurosci 2005, 6:449-462.

65. Kwak S, Weiss JH: Calcium-permeable AMPA channels in neurodegenerative disease and ischemia. Curr Opin Neurobiol 2006, 16:281-287.

66. Perry JJP, Shin DS, Getzoff ED, Tainer JA: The structural biochemistry of the superoxide dismutases. Biochim Biophys Acta 1804, 2010:245-262.

67. Haider L, Fischer MT, Frischer JM, Bauer J, Höftberger R, Botond G, Esterbauer $\mathrm{H}$, Binder CJ, Witztum $J$, Lassmann $\mathrm{H}$ : Oxidative damage in multiple sclerosis lesions. Brain 2011, 134(7):1914-1924. 
68. Stanimirovic D, Shapiro A, Wong J, Hutchison J, Durkin J: The induction of ICAM-1 in human cerebromicrovascular endothelial cells (HCEC) by ischemia-like conditions promotes enhanced neutrophil/HCEC adhesion. J Neuroimmunol 1997, 76(1-2):193-205.

69. Egan CG, Lockhart JC, Ferrell WR: Pathophysiology of vascular dysfunction in a rat model of chronic joint inflammation. J Physiol 2004, 557:635-643.

doi:10.1186/1744-9081-10-6

Cite this article as: Yu et al:: Hippocampal neuronal metal ion imbalance related oxidative stress in a rat model of chronic aluminum exposure and neuroprotection of meloxicam. Behavioral and Brain Functions 2014 10:6.

\section{Submit your next manuscript to BioMed Central and take full advantage of:}

- Convenient online submission

- Thorough peer review

- No space constraints or color figure charges

- Immediate publication on acceptance

- Inclusion in PubMed, CAS, Scopus and Google Scholar

- Research which is freely available for redistribution 